UDK: 28:34.04(497.6)-055.2

Izvorni naučni rad

Primljeno: 18.3.2019.

Prihvaćeno za štampu: 31.5.2019.

dr.sci. Elvira Islamović, vanredni profesor

Univerzitet u Bihaću

Pedagoški fakultet

elviraislamovi@gmail.com

\title{
ISLAMSKI REFORMIZAM U BOSNI I HERCEGOVINI I IMPLIKACIJE NA POLOŽAJ ŽENE
}

\section{Sažetak}

Iako u domaćoj historijsko-pravnoj literaturi postoji recentna literatura posvećena pitanjima primjene šerijatskog prava, islamskog reformizma $i$ običaja kao pomoćnog izvora šerijatskog prava u Bosni i Hercegovini, smatramo da postoji potreba da se ova pitanja sagledaju iz perspektive ženskog povijesnog iskustva. Ovaj rad ima skromne pretenzije da ublaži prazninu koja općenito postoji kada je riječ o vidljivosti žena u domaćoj historiografiji. Polazeći od historijske činjenice da je šerijatsko pravo, u većem ili manjem obliku, bilo dio pozitivnog prava u Bosni i Hercegovini od uspostavljanja osmanske vlasti pa sve do iza drugog svjetskog rata, u ovom radu teoretski se obraduje pitanje pojave islamskog reformizma sa posebnim naglaskom na promjene koje tretiraju društveni položaj žene. Izloženi evropskim/zapadnim utjecajima tokom austrougarske uprave, bosanskohercegovački muslimani bili su suočeni sa potrebom da vjersko učenje $i$ praksu kritički preispitaju $i$ prilagode novim društvenim i političkim zahtjevima. U ovom radu ćemo nastojati ukazati na neke aspekte islamskog reformizma u Bosni i Hercegovini $i$ njegove neposredne implikacije na položaj žene, u pogledu normiranja porodičnih $i$ bračnih odnosa muslimana, koristeći arhivsku gradu Arhiva Bosne i Hercegovine i Odbora islamske zajednice Cazin.

Ključne riječi: Šerijatsko pravo, Bosna i Hercegovina, islamski reformizam, žene. 


\section{Uvod}

Islamsko pravo (Šerijat) predstavlja normativni aspekt islama, a islamska pravna nauka (Fikh) jednu od najznačajnijih disciplina $\mathrm{u}$ kulturnoj historiji muslimana. Šerijat predstavlja praktičnu primjenu vjere i u sebi objedinjuje propise religijskog, moralnog i društvenopravnog karaktera. Šerijatsko pravo je u većem ili manjem obliku bilo dio pozitivnog prava u Bosni i Hercegovini u različitim društvenim i političkim okolnostima. Zastupljenost i primjena Šerijata u pravnoj kulturi muslimana i muslimanskih zemalja imala je historijske oscilacije, evoluirajući od religijskog do nacionalnog prava, odnosno od nivoa da se uzima kao jedini izvor pozitivnog prava, preko statusa jednog od izvora, do nivoa da se tretira samo kao partikularno pravo $\mathrm{u}$ statusnim pitanjima muslimana (Štulanović, 2004:7). Pred kraj osmanske uprave dolazi do sužavanja primjene šerijatskog prava i svođenja na porodične, nasljedne i vakufske odnose. Okupacijom Bosne i Hercegovine od strane Austrougarske monarhije Muslimani su dovedeni u poseban položaj, s obzirom da u okviru osmanske države nisu imali posebne vjerske organizacije kao druge vjerske zajednice. U Bosni i Hercegovini krajem 19. i početkom 20. stoljeća stvoreni su uvjeti za pojavu i širenje ideja islamskog reformizma. Među prosvijećenom ulemom i slojem muslimanske svjetovne inteligencije izražavalo se nezadovoljstvo funkcioniranjemm postojećih islamskih institucija, važećih normi tradicionalnog šerijatskog prava i normi društvenog ponašanja muslimana. U takvim okolnostima, javljaju se ideje modernizacije islamskih ustanova. Da bi takva nastojanja bila prihvaćena $\mathrm{u}$ tradicionalističkoj muslimanskoj sredini, kakva je u to vrijeme bila Bosna i Hercegovina, zahtjevi za modernizacijom su morali biti osnaženi vjersko-pravnom argumentacijom. Odgovarajuća argumentacija za tu svrhu mogla se naći u idejama islamskog reformizma modernističkog usmjerenja, čiji je osnovni sadržaj činila ideja približavanja Evropi, uz očuvanje islamske vjere i kulture (Karčić, 1990:197). Islamski reformizam je imao tri glavna aspekta: teološki, društveno-pravni i politički . ${ }^{1}$

${ }^{1}$ O Društveno-pravnom aspektu islamskog reformizma vidjeti djelo Fikreta Karčića: Društveno-pravni aspekt islamskog reformizma, Islamski teološki fakultet, 1990. 


\section{Žena u okviru šerijatsko - pravnih normi u razdoblju austrougarske uprave}

Za određivanje društvenog položaja žene u tradicionalnom društvu, važno je razlikovanje religijske pripadnosti, koja je određivala osnovna pravila socijalnog ponašanja unutar šire društvene zajednice, temeljeći ih u velikoj mjeri na normama običajnog prava. Na osnovama vjerske, običajne i kulturne tradicije uspostavljene su moralne norme, običaji i zakonodavstvo. U tradicionalnim društvima religija ima značajan upliv u uspostavljanju kriterija dopuštenosti braka, gledišta na vjernost, preljubu, rastavu braka, odnose prema djeci, roditeljima, prava nasljedstva imovine. Na osnovu religijskih gledišta država najčešće uspostavlja pravne norme koje postaju općedruštvena obaveza za sve građane. Dakle, te norme postaju dio običajnosti, tradicije ali i zakonskih rješenja većine država. Prisutne religije u Bosni i Hercegovini različito su tretirale status žene u važnim situacijama, od mogućnosti slobodnog izbora bračnog partnera i sklapanja braka, do prava na nasljeđivanje, obrazovanje, bavljenje privrednim djelatnostima, samostalno raspolaganje imovinom, pravo na razvod i dr. Decenije provedene pod austrougarskom upravom donijele su izravan kontakt sa evropskom kulturom, idejama i ustanovama. Uspostavom austrougarske vlasti u Bosni i Hercegovini održan je pravni kontinuitet u normiranju porodičnih i bračnih odnosa muslimana te nasljeđivanje. ${ }^{2}$ Austrougarska vlast je zadržala mnoge kotarske šerijatske sudove u čijoj su nadležnosti bili bračni slučajevi, porodično pravo i rastava braka. Sudovi su bili ovlašteni detaljno ispitivati slučajeve prema odredbama šerijatskog zakona te su organizacijski bili dodatak uz redovni austrijski sudski sustav. ${ }^{3}$ Vojislav Spaić je istraživao običajno nasljedno pravo kod nemuslimana na

\footnotetext{
${ }^{2}$ Uspostavljanjem osmanske vlasti i prihvatanjem islama stanovništvo Bosne i Hercegovine došlo je u doticaj sa šerijatskim pravom. Od uspostavljanja osmanske vlasti šerijatsko pravo bilo je dio pozitivnog prava u Bosni i Hercegovini. Proces islamizacije nije bio, međutim, samo prihvatanje druge vjere, već i preispitivanje cjelokupne dotadašnje tradicije u svjetlu islama (Karčić, 1997:152).

${ }^{3}$ U pogledu primjene šerijatskog prava, Austro-Ugarska je zadržala osmanski zakon o nadležnosti šerijatskih sudova iz 1860. godine, a 1883. je donesena Naredba o ustrojstvu i djelokrugu šerijatskih sudova, čime je održan pravni kontinuitet u normiranju porodičnih i bračnih stvari muslimana, te nasljeđivanje. Zbornik zakona i naredaba za Bosnu i Hercegovinu, 1883:538-542.
} 
prostoru bivše Jugoslavije u periodu austrougarske vlasti te pokazao da se u seoskim područjima i dalje primijenjivalo običajno pravo $i$ to $u$ vrlo kompleksnoj korelaciji sa šerijatskim pravom i nadopunama Austrijskog građanskog zakonika u onim odnosima koji nisu bili regulirani turskim zakonima (Spaić,1967:84). Položaj muslimanki reguliran je najvećim dijelom u okviru islamskog braka, porodice i odnosa bračnih drugova. Pristanak žene bitan je za brak i njeni roditelji ili druge osobe ne mogu joj nametnuti da se uda za onoga za koga ona nije voljna da se uda. Pored toga, muževa je obaveza u islamu da plati djevojačku opremu supruzi. Ovi darovi u potpunosti postaju i ostaju imovina supruge i njen muž ih ne može tražiti nazad u slučaju razvoda (Fathi,1996:241). Prema šerijatskom pravu brak je osnov porodice koja je temelj ljudske zajednice. Islamski brak podrazumijeva odvajanje dobara, muž nema pravo ni da uživa ni da upravlja imovinom žene, bez njezina odobrenja. U imovinskim odnosima nametnute su mužu veće dužnosti, tako on mora platiti ženi vjenčani dar i izdržavati je. Teško je, međutim sa sigurnošću reći koliko su žene u Bosni i Hercegovini u stvarnom životu koristile ova prava. Obrazovanje i poznavanje vlastitih prava, običaj, tradicija, sociokulturni i ekonomski uvjeti, određivali su obim primjene pomenutih prava. U slučaju razvoda braka, prema svojoj volji, ne navodeći razloge, muž može vrlo lako otpustiti ženu. Žena je u težoj situaciji, ona ne može u principu otkazati brak mužu koji je zlostavlja, ali ima pravo predložiti prema učenju hanefijske škole razvod braka po sporazumu, a prema učenju drugih škola ima pravo pored ovoga tražiti sudski razvod braka (ibid.,145). U braku postoji nejednakost supružnika. U ličnim odnosima mužu se priznaju šira prava. Muškarcu se također priznaje pravo da vrši disciplinsku vlast $u$ porodici, a može i raskinuti bračnu vezu svojom voljom kada to nađe za shodno. Na osnovu ugovora, bračni drugovi mogu mijenjati ne samo imovinske, nego i lične odnose. Na taj način žena može poboljšati svoj položaj, iako u stvarnom životu mnoga ograničenja onemogućavaju žene da koriste ovo pravo. Postupak sklapanja religijski mješovitog braka uključuje obavezu šerijatskog suda da upozna zaručnicu o posljedicama braka, naročito o činjenici da brak ne utiče na slobodu ispovijedanja njene vjere, da djeca nasljeđuju očevu vjeru. Supruga u ovom slučaju ima ista prava i dužnosti kao i muslimanka, osim što nema pravo naslijediti svoga muža i nema pravo biti tutor svojoj djeci iz ovoga braka (ibid.,70). U šerijatskom zakonodavstvu jedna od prvih 
objavljenih normi koja tretira propise nasljednog prava bila je opća norma koja određuje da i žene imaju pravo na nasljedstvo u čemu su izjednačene sa muškarcima:"Muškarcima pripada dio onoga što ostave roditelji i rođaci, a i ženama dio onoga što ostave roditelji i rođaci, bilo toga malo ili mnogo, određeni dio“ (Kur'an, 4:7). Ženama je dato pola nasljednog dijela muškarca koji se nalazi na istoj razini srodstva prema umrlom, a na temelju toga da uvijek postoji čovjek koji je zakonski odgovoran da izdržava ženu prema šerijatu, bilo da je to otac, brat, muž ili sin. Međutim, postoji mogućnost da se ženi da dodatni dio putem poklona tokom oporučiteljevog života ili putem posebne zakonske oporuke vasijjeta. Šerijatsko pravo je izvršilo utjecaj na nasljednopravne običaje vezane za kućne zadruge kao oblik zajedničkog vlasništva koje ima jedna porodica. U početku su članovi zadruge, koja je bila srodnička i imovinska zajednica, jedino mogli biti muškarci i samo su oni mogli imati dio u nekretninama (Spaić,75). Kasnije, navodi Spaić, ako je zadruga imala i vlastite zemlje, dobijala je sestra pri diobi te zemlje jednak dio kao i braća, a u milk-imanju polovicu muškog dijela. Štaviše, i udate sestre su imale pravo na taj dio. Sve je ovo uvedeno pod utjecajem turskog zakonodavstva i u očiglednoj je suprotnosti sa starijim običajnim pravom (ibid.). Na taj način je, navodi Spaić, šerijatsko pravo imalo pozitivan učinak na nasljednopravne običaje nemuslimana, omogućujući i ženama pravo nasljeđivanja. Prema propisima šerijatskog prava žena je nasljeđivala i miraz ili nadoknadu u novcu. Međutim, Fikret Karčić smatra kako je u ruralnim krajevima, zbog neobrazovanosti i izdvojenosti, većina muslimanskih žena bila vrlo rijetko u prilici da se koristi prednostima svog pravnog položaja (2005:139). U praksi običaj također nalaže da se kćerka odrekne roditeljske imovine u korist braće. U ovakvim situacijama običajnost je u životima ljudi imala veću snagu od prava i zakona. Ona žena koja bi se odlučila uzeti svoj nasljedni dio, učinila bi to protivno očekivanjima porodice i društvene sredine i nerijetko je smatrana uzrokom porodičnih sukoba. Za donošenje pouzdanih sudova o tome koliko su se šerijatsko-pravne norme primjenjivale u praksi i utjecale na ponašanje ljudi, a time i određivale prava i obaveze žena, potrebno je temeljito istraživanje običaja muslimanai njihovo poređenje sa šerijatskopravnim normama. U patrijarhalnim islamskim sredinama, kako navodi Riffat Hassan, tumačenje islama često ide protiv, a ne u korist žena (2003:23). Za određivanje stepena efikasnosti 
šerijatskog prava u sociološkom smislu bilo bi potrebno ustanoviti ne samo broj brakova sklopljenih pred organima Islamske zajednice, već i uticaj tih normi na daljnje ponašanje supružnika, u slučaju razvoda braka primjerice, da li muž ispunjava obavezu u pogledu mehra u okolnostima kada se na to može prisiliti i slično (Karčić, 1997:165). Islam priznaje pravo ženi da nasljeđuje imovinu $\mathrm{i}$ to pravo ne važi samo za udate žene, već je žena zakonska nasljednica i kao kćerka, sestra, majka. Prema islamskim izvorima, ulaskom u brak žena ne gubi svoju ekonomsku samostalnost upravo zbog imovine koju nasljeđuje. Žena ima pravo raspolagati vlastitom imovinom, pravo na rad i zaradu, da kupuje i prodaje. U pogledu međusobnih prava i dužnosti muškarca i žene u šerijatskom braku, osnovno pravo muževo leži u njegovoj bračnoj vlasti koju šerijatski pravnici nazivaju disciplinskom vlasti mulk-mut'a (Karčić, 1997:78). Posljedica muževe vlasti na ličnost žene ogleda se u pravu muža da određuje mjesto stanovanja, nadzire ponašanje žene, dužnosti žene da vodi domaćinstvo te da se pokorava mužu (ibid.). Orijentalna tradicija, a i islam, odnose se mnogo pozitivnije prema spolnom životu, navodi Vera St. Erlich. Asketski propisi u islamu, kao zabrana alkohola, kockanja, a na početku i kave i duhana, ne brane spolne odnose. Po šerijatskom zakonu dopušta se preudaja žene čiji muž je duže od godinu dana bio odsutan. Premda po šerijatskom zakonu prilikom razvoda braka muškarci imaju mnogo veća prava od žena, ipak se ženi daje pravo da raskine brak ako je godinu dana ostala sama. Motivacije u vezi s ljubavi i simpatijom priznate su prilikom sklapanja braka, a i u mnogim drugim prilikama (Erlich,1968:208). Prema šerijatskom pravu žena je dužna čuvati kuću i muževu imovinu, stoga je ova ženina uloga važna ne samo za moralni aspekt porodice nego i za ekonomski. Islamski pravnici potvrđuju važnost podjele uloga, ženine u porodičnom životu, odgoju i vođenju domaćinstva, a muškarčeve u društvenom i javnom životu. Muž obavlja sve javne poslove, a žena sve poslove u domaćinstvu. Muževo pravo nadzora nad ženom ogleda se u kontroli njenog kretanja i ponašanja, u cilju očuvanja ugleda porodice i očuvanja dobrih bračnih odnosa. Ona je dužna pokoravati se mužu u granicama zakona, odnosno dužna je ispunjavati svoje obaveze na način i u onoj mjeri kako to šerijat propisuje (Begović,1981:81). Žena je obavezna ispunjavati propisane dužnosti i tek od trenutka kada joj muž isplati vjenčani dar (mehr). Nepokornost žene povlači za sobom propisanu 
sankciju. U ovom slučaju mužu se priznaje pravo da disciplinski kažnjava svoju neposlušnu ženu. Muž ipak ne smije u vršenju ove disciplinske vlasti pretjerivati, a naročito pri primjeni tjelesne kazne koja se uostalom smije upotrijebiti samo u krajnjoj nuždi (ibid.). Kur'an na više mjesta skreće pažnju supružnicima na obavezu uzajamnog lijepog postupanja i plemenitosti. Uzajamni bračni sklad zavisi uglavnom od ličnosti supružnika, njihovog međusobnog uvažavanja i shvatanja važnosti bračne zajednice. U stvarnosti je vrlo teško ili nemoguće natjerati bilo koga, pogotovo represivnim mjerama na uzajamno uvažavanje, stoga je ova dužnost supružnika više etičke nego pravne prirode. Važno je razmotriti i posljedice muževe vlasti na poslovnu sposobnost žene. Prema propisima šerijatskog prava, brak niti emancipira udatu ženu niti ograničava njenu poslovnu sposobnost. Muževa vlast, kako tvrde islamski pravnici, ima čisto odgojni karakter, odnosi se na ženinu ličnost, a ne utiče na njenu sposobnost da se obavezuje ugovorima i da samostalno vodi sporove. Ona može bez odobrenja svoga muža raspolagati svojom imovinom. Dakle, brak zaključen prema šerijatskim propisima u Kraljevini SHS, ne bi imao nikakve posljedice na poslovnu sposobnost udate žene. Šerijat je, kako navodi Muharem Štulanović, u našim krajevima u višestoljetnoj primjeni prošao divergentan evolutivni put. Na kraju toga historijskog puta, Šerijat je, dominirajućim pozitivnim pravnim porecima, sveden $\mathrm{u}$ domen lične primjene i prakse ili, sociološki gledano, u sistem etičkih religioznih normi, tradicije i običaja (2004:35).

\section{Refleksije reformističkog pokreta na položaj žene u Bosni i Hercegovini}

Izloženi evropskim/zapadnim utjecajima, bosanskohercegovački muslimani bili su suočeni sa izazovom da vjersko učenje i praksu kritički preispitaju i prilagode društvenim potrebama novoga vremena. Tradicionalni obrasci ponašanja ljudi mijenjali su se sporo, ali neminovno, stoga je bilo potrebno uložiti napore da se vjersko učenje i praksa prilagode novim društvenim okolnostima. Reformizam je obuhvatio niz društvenih pitanja, uključujući i pitanja koja se tiču socijalnog položaja žene. Promjene u važećem šerijatskom pravu, kada je u pitanju položaj muslimanske žene, odnosile su se na pitanja raskida braka, oblika bračne zajednice i proglašenja nestalih lica za umrle. Prvi 
akt kojim je izvršena promjena tradicionalnog hanefijskog tumačenja $\mathrm{u}$ Bosni i Hercegovini bila je Okružnica Vrhovnog šerijatskog suda u Sarajevu od 30. XII 1895. godine o uputstvu za razrješenje braka žena ostavljenih bez opskrbe sa odsutnim mužem. ${ }^{4}$ Ova promjena nastala je kao izraz socijalne potrebe da se zbrinu žene čiji su muževi nestajali ili se iseljavali iz Bosne i Hercegovine, nakon što je ženama četiri godine uskraćeno pravo na izdržavanje. Korak dalje otišlo se s Okružnicom Vrhovnog šerijatskog suda od 4. XII 1916. godine kojom je naređeno šerijatskim sudovima da zabrane vjenčavati više od jedne žene licima kojima to imovinske ili zdravstvene prilike ne dopuštaju. $^{5}$ Ovo prvo sudsko ograničavanje poligamije u Bosni i Hercegovini uslijedilo je na inicijativu Zemaljske vlade koja se u toku ratne 1916. godine suočila sa problemom poligamnih brakova vojnih obveznika islamske vjeroispovijesti, čijim je suprugama vlada bila obavezna isplaćivati ratnu potporu. ${ }^{6}$ Da bi se spriječile zloupotrebe $u$ tom pogledu, Zemaljska vlada je uz odobrenje Ulema medžlisa ograničila takvu praksu. U Okružnici reis-ul-uleme 1918. godine, govori se i o naredbi Zemaljske vlade upućene svim oblastima u zemlji, o sprječavanju "konkubinata pričuvničkih žena" te sankcioniranju prijavljenih slučajeva. ${ }^{7} \mathrm{Na}$ istom mjestu, upozorava se na opadanje islamskog morala i istinskih vrijednosti, za šta se odgovornim prevenstveno smatraju muškarci. Također, ističe se da je usljed ratnih okolnosti velik broj žena i djece ostao socijalno nezbrinut te upozorava na islamom utvrđenu obavezu muškaraca da se brinu za žene. Također je činjenica da i naši muškarci popuštaju u hamijjetu $i$ ahlaku, dapače oni daju povoda kvarenju naših žena. A najžalosnije je, da se nađe pojedinaca, koji nevinu djevojku unesreće dapače i za koru hljeba ili šaku brašna... Pravo rekavši, muškarci daju pravac ženama $i$ u pogledu hamijjeta i u pogledu ćudorednosti. Za to će odbori (ustrojeni radi suzbijanja nemorala, op.a.), koji se budu osnivali u navedenu

\footnotetext{
${ }^{4}$ Zbirka naredaba za šeriatske sudove u BiH 1878-1900, Zemaljska vlada za BiH i Vrhovni sud za BiH. U Karčić, 1990:208.

${ }^{5}$ Ibid.

${ }^{6}$ Ibid.

${ }^{7}$ Arhivska građa Odbora Islamske zajednice Cazin, Okružnica Reis-ul-uleme za BiH, broj 220/1918. 25.2.
}

1918. 
svrhu, imati dužnost, da na prvom mjestu djeluju na popravljanje morala samih muškaraca, pa da bude cijela zajednica, kao što treba. Ne treba se varati, da ćemo mi svoje društvo popraviti, ako mi hoćemo da liječimo samo jednu polovicu a druga da ostaje zanemarena. Drukčije je i nemoguć pouzdan popravak naše zajednice. Uz ove napomene treba nam uzeti naoko $i$ današnje vrijeme, a osobito ovo ratno doba, jer je - što se reče - borba za opstanak izvela mnogu u istinu čestitu i čednu muslimanku, koja se je osjećala najudobnije u svom boravištu, zaklonjenu od talasa javnog života, zabavljenu kućnim poslovima $i$ njegovanjem svoje djece. Potreba da nahrani sebe $i$ ostavljenu, neopskrbljenu djecu, opravdano ju je izvela u javni saobraćaj, da se ne skapava od gladi! Kad se jedan put rat dokonča, smanjiće se broj onih, koje su danas prinuđene, da idu u čaršiju i na sud. Ali $i$ poslije rata osobito u većim mjestima će opet biti dosta samohranih. I što koji grad više raste, to će u njemu biti sve više takovih. Hoćemo li dakle, da nam žene budu kako valja, treba, da muslimani budu vrijedni, požrtvovani, hamijjetli, pa da se uz to čvrsto zauzmu, kako da se nađe i osigura opskrba onih samohranih žena. ${ }^{8}$

Za rješavanje nastalih socijalih problema, pozvani su Muftijski uredi i vakufska povjerenstva da formiraju odbore koji će: 1) bdjeti nad očuvanjem narodne čistoće, odvraćajući ona lica, koja skrenu sa pravog puta; 2) voditi brigu o onim samohranim ženama i pomagati im nabavljanje životnih namirnica; 3) nastojati, da se ženama sposobnim za rad nađe zaposlenje 4) osnivati fondove za nemoćne siromahe, $\mathrm{u}$ koji bi se sakupljali dobrovoljni prilozi, a mogao bi se i zekat u ove fondove ulagati.

O sklapanju braka u praksi šerijatskih sudova govori i okružnica Reisul-uleme za Bosnu i Hercegovinu iz 1917. godine, u kojoj se upozoravaju imami da se strogo drže propisa. U okružnici se navodi kako je stigla pritužba od jednog šerijatskog suda ulema - medžlisu, da neki imami provode vjenčanja bez izuname (murasele). Ali postoje i takvi slučajevi, navodi se u okružnici, ,kad šerijatski sud ne može da izda izunnamu, zbog toga što nije istekao iddet udovoj ili puštenoj, koja hoće da se ponovo uda, ili se nije ustanovila smrt vojnika, za

\footnotetext{
${ }^{8}$ Ibid.

${ }^{9}$ Ibid.
} 
kojeg se misli da je poginuo ili da je izgubljen, kako to šerijatski propisi zahtijevaju; ili što vojni obaveznik nije pribavio dozvole od strane vojne oblasti, da se može vjenčati i tome slično, kada dakle šerijatski sud ne može vjenčanja obaviti niti izunnamu izdati zbog šerijatskih ili upravno-vojnih zapreka“. I u takvim slučajevima neki imami provode vjenčanja, koja po šerijatu nisu valjana ili su zabranjena prema upravno-vojničkim propisima. U okružnici se opominju imami i hodže, koji obavljaju vjenčanja, koji ni u kojem slučaju ne smiju obavljati vjenčanja (nikaha) bez dozvole šerijatskog suda. Također se navodi da je isključiva nadležnost šerijatskih sudova izdavanje izunnama, dozvola za vjenčanje, koji znaju propise ,kada i kako se može tko oženiti odnosno udati“، "Imami pak dužni su, kad se tko oženi, izdati ilmihaber i potpisati ga, odnosno muhurlejsati sa muhtarom, a vjenčanje obaviti samo onda, kada kadija izda izunnamu (muraselu) $)^{\text {“ }} .^{10}$ Da šerijatske odredbe koje štite prava žene nisu uvijek u praksi poštovane, svjedoči i molba za uspostavljanje disciplinarnih bračnih sudova pri muftijskim uredima, kako bi se osigurao šerijatski legitimitet talaka (puštanja žene), ali i pravo žene na razvod ako je predmet muževljeve samovolje i maltretiranja. Zaštita prava žena, zatražena je predstavkom prosvjetnog i potpornog društva Spas upućenog reis-ul-ulemi Džemaludinu ef. Čauševiću, prilikom posjete u Banja Luci 1919. godine (Jahić, 2004:44). Stupanjem u brak podrazumijevalo se da muškarac preuzima sve moralne i materijalne obaveze prema svojoj ženi. Poligamni brakovi nisu bili nepoznata činjenica u Bosni i Hercegovini, no nisu bili ni tako rašireni kao u nekim drugim zemljama Islamskog svijeta. Pitanje poligamije bilo je jedno od najčešće diskutiranih pitanja među muslimanima krajem 19. i početkom 20. stoljeća. Islam dozvoljava ženidbu jednog muškarca sa (najviše) četiri žene uz ograničenja. Muž mora biti u mogućnosti da podjednako ekonomski osigura život svake žene pojedinačno i to na način i u obimu koji odgovara njenom socijalnom porijeklu i statusu, da bude pravedan i jednako postupa prema svakoj ženi i što je najvažnije da prva žena odobri svojevoljno i bez prisile novi brak svome mužu. Teško je sa sigurnošću reći koliko je u praksi poštovan uvjet ${ }^{10}$ Arhivska građa Odbora islamske zajednice Cazin, Okružnica Reis-ul-ulema za
Bosnu i Hercegovinu,

Broj 2123/1917, Sarajevo 4. 11. 1917. 
davanja ženine saglasnosti za dovođenje druge žene i svi uvjeti kada je o pravednosti riječ. Žensku ljubomoru kod poligamije ublažava činjenica da je rad za svaku pojedinu ženu olakšan kad ih ima više. Kada je muž dovodio mlađe žene a starije zanemarivao, ove su bile nezadovoljne i nesretne. Kod tradicionalnih poligamija obično nema sporova, zahvaljujući pravilima kojih se svi strogo drže. Obično je prva žena domaćica, ona ima pravo da određuje, a uživa i neke druge privilegije. Često muž mora dobiti njen pristanak kad bira drugu ženu. Često mu žena sama nađe ili preporuči svoju sestru, rođakinju ili prijateljicu. Po šerijatskom pravu muž ima dužnost da sa ženama jednako postupa, da im posveti dovoljno vremena, da im na jednak način posveti pažnju i da ih jednako opskrbljuje. Razlozi za poligamni brak najčešće su bolest supruge, nemogućnost rađanja djece, pogotovo muške, što treba primiti sa rezervom, jer uzrok steriliteta mogu biti oba supružnika, nerijetko samo muškarac, i dr. Najviše slučajeva poligamije zabilježeno je u Bosanskoj Krajini. Islamsko-šerijatsko pravo ponudilo je višeženstvo kao rješenje i preventivnu zaštitu od bluda i nezakonitih seksualnih odnosa izvan bračne zajednice. Kur'an propisuje: "Onda se ženite sa onim ženama koje su vam dopuštene, sa po dvije, sa po tri, i sa po četiri. A ako strahujete da nećete pravedni biti, onda samo sa jednom“(An-Nisa, 3). Kur'an, komentirajući pojam pravednosti, objašnjava ljudima da je nemoguće postići pravednost, makar tome težili, već da nastoje izbjeći preferiranje jedne od supruga: "Ali ne dopustite sebi takvu naklonost pa da jednu ostavite u neizvjesnosti““ (An-Nisa,129). Kada je riječ o pravednosti na polju emocija i osjećanja, ona je gotovo neostvariva i veoma je teško postići je. Na osnovu popisa stanovništva iz 1910. godine, u Bosni i Hercegovini je zabilježen sljedeći broj poligamnih brakova (Kozličić, 1999:28): 
Brakovi sa više žena

\begin{tabular}{|c|c|c|c|c|c|c|c|c|}
\hline \multirow{2}{*}{$\begin{array}{l}\text { Okrug } \\
\text { broj } \%\end{array}$} & \multicolumn{2}{|c|}{ dvije } & \multicolumn{2}{|c|}{ tri } & \multicolumn{2}{|c|}{ četiri } & \multicolumn{2}{|c|}{ ukupno } \\
\hline & broj & $\%$ & broj & $\%$ & & broj $\%$ & & \\
\hline Banja Luka & 115 & 9,70 & 2 & 5,56 & 0 & 0,00 & 117 & 9,57 \\
\hline Bihać & 571 & 48,19 & 22 & 61,11 & 1 & 100,00 & 594 & 48,61 \\
\hline Mostar & 56 & 4,73 & 1 & 2,78 & 0 & 0,00 & 57 & 4,67 \\
\hline Sarajevo & 125 & 10,55 & 3 & 8,33 & 0 & 0,00 & 128 & 10,47 \\
\hline Travnik & 69 & 5,82 & 0 & 0,00 & 0 & 0,00 & 69 & 5,65 \\
\hline Tuzla & 249 & 21,01 & 8 & 22,22 & 0 & 0,00 & 257 & 21,03 \\
\hline $\mathrm{BiH}$ & 1.185 & 100,00 & 36 & 100,0 & 1 & 100,00 & 1.222 & 100,00 \\
\hline
\end{tabular}

Prema ovim podacima, najviše poligamnih brakova bilo je u bihaćkom okrugu, a najmanje u mostarskom. Iz ovih statističkih podataka vidi se da su brakovi sa dvije žene bili najčešći, brakovi sa tri žene bili su rjeđi, ali ih je ipak bilo, posebno u Krajini. Brak sa četiri žene nije često dozvoljavan i bio je rijedak, ali je ipak zabilježen na području Sreskog šerijatskog suda u Cazinu. Jedan od najčešćih razloga koji se navode za sklapanje poligamnih brakova jest u procentu više žena nego muškaraca. Međutim, popis stanovništva iz 1910. godine pokazuje veći broj muškaraca nego žena. Naime, prema popisu, muškaraca muslimana je bilo 327.421, a muslimanki 284.716. Poligamni brakovi u Bosni i Hercegovini sklapani su uz prethodnu dozvolu šerijatskog suda. Razlozi za sklapanje poligamnih brakova su različiti. Molba za sklapanje poligamnog braka upućivala se prvostepenom šerijatskom sudu. Sud bi na osnovu ponuđenih razloga za takav brak i uz svjedočenje vjerodostojnih svjedoka, koji bi potvrdili istinitost navoda, dozvoljavao ili osporavao takav brak. Jedan od odlučujućih uvjeta za poligamni brak bila je imovinska situacija muža, gotovo odlučujući element u prihvaćanju ili odbijanju molbe za poligamni brak. Muževi su često isticali da su povoljnog materijalnog stanja da mogu izdržavati više od jedne žene. Žena ima pravo kod sklapanja bračnog ugovora uvjetovati mužu da ne može živjeti u bračnoj zajednici sa više žena. Monogamija je ipak poželjnija od poligamije koja se prakticira rijetko i u posebnim uvjetima. Poligamiji se ne pribjegava, osim u slučajevima nužde, potrebe ili nekog opravdanog objektivnog i subjektivnog razloga. 


\section{Zaključak}

$\mathrm{Na}$ ovom povijesnom socijalnom prostoru za određivanje društvenog položaja žene važno je razlikovanje religijske pripadnosti, koja određuje osnovna pravila socijalnog ponašanja unutar šire društvene zajednice, temeljeći ih u velikoj mjeri na normama običajnog prava. $\mathrm{Na}$ osnovu vjerske, običajne i kulturne tradicije uspostavljene su moralne norme, običaji i zakonodavstvo. Religija ima značajan upliv $u$ uspostavljanju kriterija dopuštenosti braka, gledišta na vjernost, preljubu, rastavu braka, odnose prema djeci, roditeljima, prava nasljedstva imovine. Položaj muslimanki reguliran je najvećim dijelom u okviru islamskog braka, porodice i odnosa bračnih drugova. Prema šerijatskom pravu brak je osnov porodice koja je temelj ljudske zajednice. Na osnovu ugovora, bračni drugovi mogu mijenjati ne samo imovinske, nego i lične odnose. Na taj način žena može poboljšati svoj položaj, iako u stvarnom životu mnoga ograničenja onemogućavaju žene da koriste ovo pravo. U šerijatskom zakonodavstvu jedna od prvih objavljenih normi koja tretira propise nasljednog prava bila je opća norma koja određuje da i žene imaju pravo na nasljedstvo u čemu su izjednačene sa muškarcima. Šerijatsko pravo imalo je pozitivan učinak na nasljednopravne običaje i nemuslimana, omogućujući i ženama pravo nasljeđivanja. Prema propisima šerijatskog prava žena je nasljeđivala i miraz ili nadoknadu u novcu. Teško je, međutim sa sigurnošću reći koliko su žene u Bosni i Hercegovini u stvarnom životu koristile ova prava. Obrazovanje i poznavanje vlastitih prava, običaji, patrijarhalna tradicija, sociokulturni i ekonomski uvjeti, određivali su obim primjene pomenutih prava. U ruralnim krajevima, zbog neobrazovanosti i izdvojenosti, većina muslimanskih žena bila je vrlo rijetko u prilici da se koristi prednostima svog pravnog položaja. Za donošenje pouzdanih sudova o tome koliko su se šerijatsko-pravne norme primjenjivale u praksi i utjecale na ponašanje ljudi, a time i određivale prava i obaveze žena, potrebna su temeljita istraživanja običaja muslimana i njihovo poređenje sa šerijatskopravnim normama. $\mathrm{Na}$ žalost, u patrijarhalnim islamskim sredinama, tumačenje islama često ide protiv, a ne u prilog žena.

Izloženi evropskim/zapadnim utjecajima, bosanskohercegovački muslimani bili su suočeni sa izazovom da vjersko učenje i praksu kritički preispitaju i prilagode društvenim potrebama novoga vremena. 
Tradicionalni obrasci ponašanja ljudi mijenjali su se sporo, ali neminovno, stoga je bilo potrebno uložiti napore da se vjersko učenje i praksa prilagode novim društvenim okolnostima. Reformizam je obuhvatio i pitanja koja se tiču socijalnog položaja žene. Promjene u važećem šerijatskom pravu, kada je u pitanju položaj muslimanske žene, odnosile su se na pitanja raskida braka, oblika bračne zajednice i proglašenja nestalih lica za umrle. Prvi akt kojim je izvršena promjena tradicionalnog hanefijskog tumačenja u Bosni i Hercegovini bila je Okružnica Vrhovnog šerijatskog suda u Sarajevu 1895. godine o uputstvu za razrješenje braka žena ostavljenih bez opskrbe sa odsutnim mužem, koja je nastala kao izraz socijalne potrebe da se zbrinu žene čiji su muževi nestajali ili se iseljavali iz Bosne i Hercegovine, nakon što je ženama četiri godine uskraćeno pravo na izdržavanje. Korak dalje otišlo se s Okružnicom Vrhovnog šerijatskog suda iz 1916. godine kojom je naređeno šerijatskim sudovima da zabrane vjenčavati više od jedne žene licima kojima to imovinske ili zdravstvene prilike ne dopuštaju. Ovo prvo sudsko ograničavanje poligamije u Bosni i Hercegovini uslijedilo je na inicijativu Zemaljske vlade koja se u toku ratne 1916. godine suočila sa problemom poligamnih brakova vojnih obveznika islamske vjeroispovijesti, čijim je suprugama vlada bila obavezna isplaćivati ratnu potporu. Usljed ratnih okolnosti velik broj žena i djece ostao je socijalno nezbrinut, protivno islamom utvrđenom obavezom muškaraca da se brinu za žene i djecu. Da šerijatske odredbe koje štite prava žene nisu uvijek u praksi poštovane, svjedoči i molba za uspostavljanje disciplinarnih bračnih sudova pri muftijskim uredima, kako bi se osigurao šerijatski legitimitet talaka (puštanja žene), ali i pravo žene na razvod ako je predmet muževljeve samovolje i zlostavljanja. Na temelju gore navednog, može se zaključiti kako se kulturne prakse u nekim islamskim sredinama pod utjecajem patrijarhata i određenih običaja, nerijetko koristite za podčinjavanje žena i uskraćivanje njihovih prava. Bez obzira na razlike između muškaraca i žena, oni imaju zajednička prava i obaveze u društvu i snose kolektivnu odgovornost prema društvu u cjelini kao neodvojivi članovi društva. 


\section{Izvori i literatura}

\section{Knjige}

1. Kur'an s prevodom. Korkut, B., Medina.

2. Begović, M. (1981). Šerijatsko bračno pravo. Beograd.

3. Erlich St. V. (1971). Jugoslavenska porodica u transformaciji. Liber. Zagreb.

4. Erlich St. V. (1968).U društvu s čovjekom. Naprijed. Zagreb.

5. Es- Sibai, M. (2004). Žena između šerijatskog i svjetovnog prava. Zenica.

6. Hasann, R. (2003). Are Human Rights Compatibile with Islam. U Bakšić Muftić J., Zbornik radova Integriranje principa ravnopravnosti spolova u odgojno-obrazovni sistem BiH. Sarajevo.

7. Hofmann, M. (1996). Islam kao alternativa. Bemust. Sarajevo.

8. Imamović, M. (1997). Pravni položaj i unutrašnjopolitički razvitak BiH od 1878-1941. Sarajevo.

9. Islamović, E. (2018). Žene u povijesti Bosne i Hercegovine u 20. stoljeću. Preporod. Kulturno društvo Bošnjaka Hrvatske. Zagreb.

10. Jahić, A. (2004). Hikjmet - riječ tradicionalne uleme u Bosni $i$ Hercegovini. Tuzla.

11. Karčić, F. (1990). Društveno-pravni aspekt islamskog reformizma.Islamski teološki fakultet. Sarajevo.

12. Karčić, F. (1997). Studije o šerijatskom pravu. Zenica.

13. Karčić, F. (2005). Šerijatski sudovi u Jugoslaviji 1918.-1941. Sarajevo.

14. Kozličić, M. (1999). Stanovništvo i naselja Unsko-sanskog područja 1879-1921. Bihać.

15. Osman, F. (1996). Prava muslimanske žene u porodici i društvu. U Ljudska prava u kontekstu islamsko-zapadne debate. (Prir.) Karić, E. Pravni centar, Fond otvoreno društvo BiH. Sarajevo.

16. Spaić, V. (1967). Nasljednopravni običaji u BiH nakon austrougarske okupacije. Radovi, Knjiga XXXII, Odjeljenje društvenih nauka ANUBiH. Sarajevo.

17. Štulanović, M. (2004). Urf. Običaj kao pomoćni izvor šerijatskog prava, sa osvrtom na Bosnu i Hercegovinu. Islamska pedagoška akademija. Bihać.

18. Štulanović, M. (2018). Komparativno porodično pravo - brak. Komparacija islamskog \& pozitivnog bračnog prava Federacije BiH $\mathrm{i}$ zemalja regije. Islamski pedagoški fakultet Bihać. 
Neobjavljena građa

19. Arhiv Bosne i Hercegovine

20. Arhivska građa Odbora islamske zajednice Cazin 


\section{Elvira Islamovic, $\mathbf{P h D}$ \\ University of Bihac \\ Pedagogical Faculty \\ elviraislamovi@gmail.com}

Original scientific article

\section{ISLAMIC REFORMISM IN BOSNIA AND HERZEGOVINA AND IMPLICATIONS ON THE WOMEN'S POSITION}

\section{ABSTRACT}

Although there is recent literature in domestic historical and legal literature on the issue of the application of Sharia law, Islamic reformism and customs as an auxiliary source of sharia law in Bosnia and Herzegovina, we believe that there is a need for these issues

from the perspective of women's historical experience. This paper has modest pretensions to alleviate the void that generally exists when it comes to the visibility of women in domestic historiography. Starting from the historical fact that Sharia law, in greater or lesser form, was part of a positive law in Bosnia and Herzegovina from the establishment of the Ottoman authorities to the end the Second World War, in this paper theoretically the issue of occurrence of Islamic reformism with a special emphasis on changes that treat the social position of women is dealt with. Exposed to the European / Western influences during the Austro-Hungarian administration, Bosnian Muslims were faced with the need to critically review religious practice and practice and adapt them to new social and political demands. In this paper we will try to point out some aspects of Islamic reformism in Bosnia and Herzegovina and its immediate implications for the position of women in terms of standardizing the family and marital relations of Muslims using the archives of the Archives of Bosnia and Herzegovina and the Committee of the Islamic Community Cazin.

Keywords: Sharia Law, Bosnia and Herzegovina, Islamic Reformism, Women. 


\section{الأستاذ المشارك الدكتور سيدة ألويرة إسلاموفيتش \\ الإصلاحية الإسلامية في البوسنة والهرسك وتبعاتها على موقع المرأة \\ الخلاصية}

على الرغم من احتواء المكتبات المحلية على المؤلفات التاريخية الفقهية المحققة التي

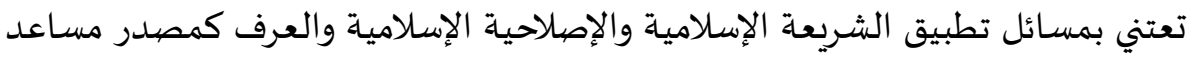

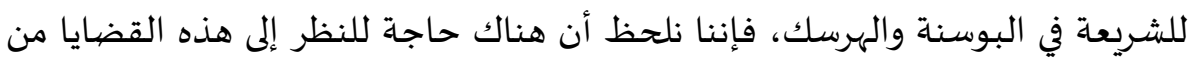

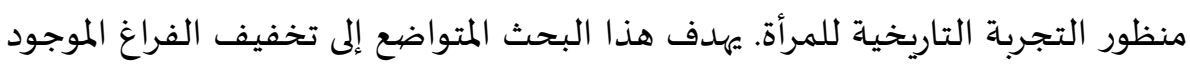

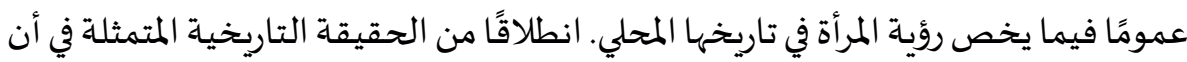

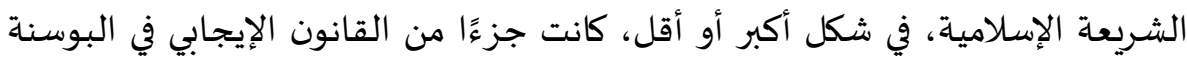

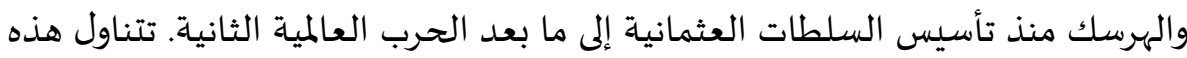

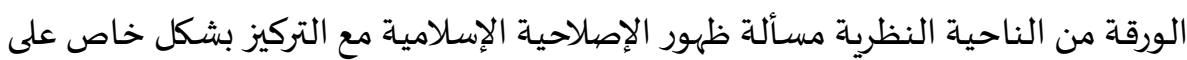

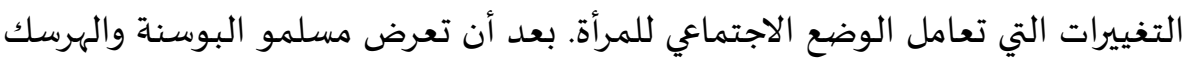

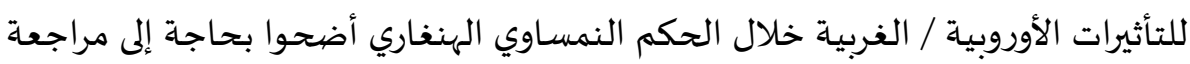

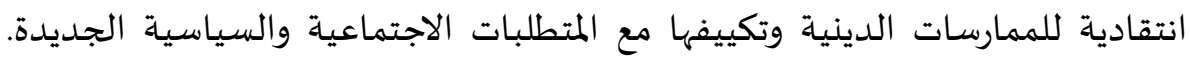

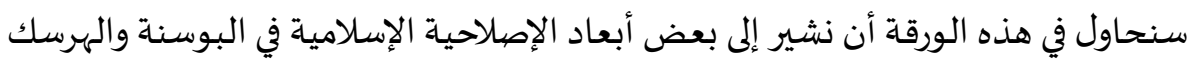

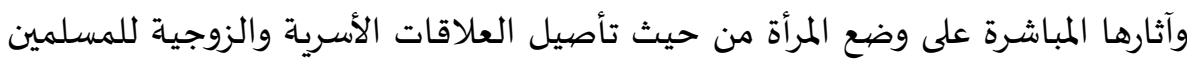

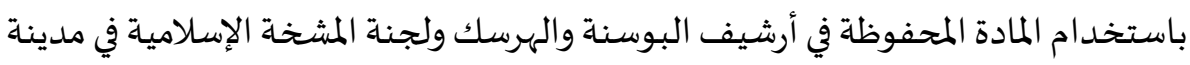
تسازين.

الكلمات المفتاحية: الشريعة، الفقه الإسلامي، البوسنة والهرسك، الإصلاحية

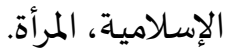

